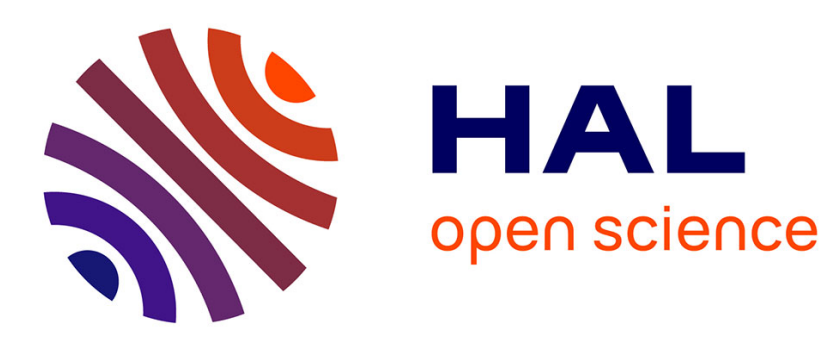

\title{
A paradigm of the circular economy: the end of cheap nature?
}

\author{
Jean Pierre Doussoulin
}

\section{To cite this version:}

Jean Pierre Doussoulin. A paradigm of the circular economy: the end of cheap nature?. Energy, Ecology and Environment, In press, 10.1007/s40974-019-00145-2 . hal-02542701

\section{HAL Id: hal-02542701 https://hal.science/hal-02542701}

Submitted on 14 Apr 2020

HAL is a multi-disciplinary open access archive for the deposit and dissemination of scientific research documents, whether they are published or not. The documents may come from teaching and research institutions in France or abroad, or from public or private research centers.
L'archive ouverte pluridisciplinaire HAL, est destinée au dépôt et à la diffusion de documents scientifiques de niveau recherche, publiés ou non, émanant des établissements d'enseignement et de recherche français ou étrangers, des laboratoires publics ou privés. 
Original article in Energy Ecology Environement.

https://link.springer.com/article/10.1007\%2Fs40974-019-00145-2

Cite this article as: Doussoulin, J.P. Energ. Ecol. Environ. (2019).

https://doi.org/10.1007/s40974-019-00145-2

\section{A Paradigm of the Circular Economy: The End of Cheap Nature?}

Jean Pierre Doussoulin

Université Paris-Est Marne-la-Vallée, France

jean-pierre.doussoulin@u-pem.fr

\section{ABSTRACT.}

This article proposes a new definition of the circular economy following analysis and comparison of the most prominent concepts of the biosphere: Sraffa's value theory and Moore's dialectical method. Our paper helps to identify the positions of each of these concepts with regard to free disposal, waste treatment and surplus distribution value. Thus, we are able to show that the mechanisms of the circular economy function simultaneously as part of the appropriation system and as part of the system for the protection of nature. This study enriches the literature on the circular economy by providing analysis of various scenarios of waste disposal. Finally, areas of application and policy implications of the small wins theory are explored in order to guide future research on the circular economy.

Keywords: capitalism; environment; political economy; Sraffa's value theory

JEL codes: P26,Q57, R15 


\section{Introduction}

The aim of the circular economy is to reduce the negative impacts of the linear economy (Korhonen, Honkasalo, and Seppälä 2018). It presents a shift in industrial practices in support of a steady state economy (Daly 2011; Geissdoerfer et al. 2017), but it is not a silver bullet to resolve the issues of planetary pollution and raw material depletion.

The relationship between the circular economy and sustainability is not often made explicit in the literature (Geissdoerfer et al. 2017). In the rush to get commitment to the concept of the circular economy, society needs to consider the possibility of an unintended corollary. This paper attempts to analyze the circular economy as a new paradigm of sustainability involving the biosphere, the economic systems and the methods of distributing surplus value.

The significance of this study is that it addresses the criticisms of the circular economy by considering that sustainability is increasingly relevant in science and technology today. The increased demand for sustainable production processes justifies the need for more effective policies with a focus on zero waste. Therefore, this study will provide an alternative view of the incineration process proposed by the small wins theory.

The paper is structured as follows, Part 2 outlines some controversial issues from ecological economics for the biosphere and the widely discussed concept of industrial ecology dealing with waste disposal and valorization called Cradle to Cradle (McDonough and Braungart 2010). This section also briefly introduces Sraffa's value system and lays out Sraffa's value equation for a donor-internal system. This means that system is composed of donor and internal processes. The donor process contributes the inputs or resources to the system. The internal process uses these inputs to produce an output or product. Part 3 uses a simplified model to present some waste management 
methods as alternatives to landfill. In these alternative scenarios, the circular economy could, in principle, regenerate some valuable inputs. These didactic examples, reinterpreted to express the asymmetrical political relationship between the biosphere and the economy, are then analysed.

\section{Methodology}

The methodology used in this paper takes different dimensions into account. The first one, inspired by the definition of the biosphere proposed by Vernadsky (1926), analyzes the pathways of molecules in the biosphere. The second, closer to the perspective supported by Sraffa (1960), attempts to reconstruct a history of economics based on the interface between the economy and the environment. The third, inspired by Moore's dialectical method (Moore 2015), confronts the positions of the actors involved in the regulation of boundaries between the appropriation processes of the economy and preservation of the environment.

\subsection{Impacts of the Circular Economy on the biosphere}

The first dimension of our methods analysis provides a physical description of the biochemical cycles. The aim is to clarify the structures and the exchanges between the components of the system, so as to identify opportunities for change or improvement in

the physical flows in the cycles. These exchanges determine the nature, limits and dimensions of the cycles.

It is particularly difficult to establish a global, fixed and homogeneous view of the current configuration of each cycle since the beginning of the climate change issue, as has been pointed out by many researchers. Our analysis, however, tends to focus on the disruption of natural cycles. In addition, the biosphere is highly influenced by the 
physicochemical parameters of each of the other components of the Earth system, such as the atmosphere, the lithosphere and the hydrosphere.

Vernadsky's definition of the biosphere takes a biochemical and thermodynamic perspective. Indeed, thermodynamics indicates that, in a condition of maximum entropy, heat dissipates irreversibly following Carnot's principle: consequently, no mechanical equivalent is produced. Vernadsky noted one particular feature of the growth of green plants and autotrophic bacteria i.e. that it produces "negative entropy" or negentropy. This apparent contradiction of the Carnot and Clausius principles lays the foundation for the theory of the accumulation of energy in the geosphere (Loiret 2016). More precisely, this energy accumulation or storage acts as a geochemical indicator of the work of nature (in Joules) as free energy: exergy (Chen 2016). In addition, Vesnadsky notes the difference between geochemical and biochemical energies: geochemical energy measures energy storage in the compartments of the geosphere, i.e. the atmosphere, lithosphere and hydrosphere, but it does not account for the energy of living systems such as ATP (adenosine triphosphate).

In a series of articles published in 1948, G. E. Hutchinson, proposed the existence of close ties between the geochemical and biochemical cycles, in other words between the geosphere and the living world (Hutchinson 1948). These articles were inspired by Lotka and Vernadsky'sapproach to measuring carbon metabolism (Deléage 1989). G. E. Hutchinson and the Odum brothers were the first to consider the ecosystem as a thermodynamic machine capable of maintaining a state of internal order or low entropy.

Living tissue is thus an important component of the surface of our planet according to Vernadsky (Vernadsky 1926). Moreover, following the geochemical tradition, Alfred Lotka proposed a mathematical model of physical biology. Lotka drew a parallel between 
the evolution of organisms and the evolution of their physical environment; their adaptation to their environment and vice versa (Lotka 1922). In this way, Lotka, American mathematician, physicist and statistician, introduced a new scientific discipline in his work Elements of Physical Biology (Lotka, 1926) which aims to apply the laws of physics to biological systems. Indeed, Lotka, a contemporary and admirer of Vernadsky, proposed a global approach to the world system that paved the way for the theory of systems ecology, a field which was later developed by Hutchinson and Odum (Taylor 2010).

In this representation of the world, the mineral sphere as well as the living world are not only the components of a global system of degradation or dissipation of energy but are also part of a more complex system. In his book Fundamentals of Ecology (1971), Odum puts forward his theory of the relationship between human activities and natural processes. Recent advances in the field support the notion of complex adaptive systems which imply that a system is capable of adapting to its environment through mechanisms such as phenotypic plasticity (Levin 1992; Levin andLelvin 1999).

According to Podolinsky, although society profoundly modifies its environment, the biosphere presents a major limitation to its growth (Podolinsky 1880). Through the lens of ecological Marxism, Podolinsky proposed the idea of a metabolic relationship between man and nature using the theory of accumulation of energy (Foster and Burkett 2004).

Human development is at a stage where the focus is no longer on industrial growth, as it was during the Industrial Revolution. This new development is defined by the anthropocene through post-industrial growth, which puts the human being at the center (Crutzen 2006; Crutzen and Steffen 2003; Steffen, Crutzen, and McNeill 2007). The development of more sustainable activities is seen as an opportunity for the green 
economy. For example, the resource-consuming system of agricultural production which uses large amounts of nitrogen and phosphorous becomes highly entropic. (Billen, Lassaletta, and Garnier 2014; Carpenter and Bennett 2011; Domene and Ayres 2001). The question arises whether the rural and urban economies have made optimum use of resources (Daly 1992).

In a prospective hypothesis, the linear economy extracts raw materials from the biosphere to produce outputs and throws the waste back into the biosphere. (Daly 1985; Haas et al. 2015). However, the biosphere cannot be assumed to be completely on this linear path as it is also determined by cycles (Giampietro 2019).

In the case of the use of natural resources, by integrating biosphere processes to form virtuous loops, the circular economy brings about a reduction in the consumption of exhaustible natural resources by shifting to environmental systems, thereby reducing the consumption of exhaustible fossil fuels and decreasing net waste emissions (Korhonen, Honkasalo, et al. 2018).

We can see that paths of certain chemical molecules are circular and/or linear depending on the temporality (Ayres 1997). From this perspective, the annual agricultural cycle involves the intensive use of chemicals that pollute soils and streams with very long cycles involving the natural synthesis of nitrogen and phosphorus (Billen et al. 2014; Le Noë, Billen, and Garnier 2017).

With recycling, through looped economic processes, the circular economy leads to a reduction in the consumption of resources (Allenby 1992; Zink and Geyer 2017). However, it is not enough to correct the situation or close the loops, it is equally important to reinforce policies aimed at promoting a less industrialized economy with lower carbon emissions, more energy-saving and lower usage of non-renewable natural resources like 
nitrogen and phosphorus (Grizzetti et al. 2013; Le Noë et al. 2017).

\subsection{Sraffa's value theory}

In this paper, the use of Sraffa's approach provides a framework for the value relationship between the economic system and the biosphere. It is generally assumed that each unit of commodity has the same value. In Sraffa's theory, value means the exchange ratio which would allow the system to be reproduced and any surplus created to be distributed to the different agents in their roles as wage-earners, investors, owners, as well as the state, if taxes are included (Burmeister 1984; Sraffa 1960).

A value theory means that a value is attributed to each good or service produced by the system, so that each commodity can be exchanged for a quantity of another commodity.

It is difficult to precisely measure the flow of commodities or natural resources between the biosphere compartments if they are not considered in connection with the value of those commodities or natural resources (Daly 1985; Duchin 2009; Haas et al. 2015).

On the other hand, it is illusory to believe that if ecological resources are integrated, prices will be fairer or more sustainable (Ayres 1998). We can choose to represent the ecological resources, but this means attributing a price to them (Patterson 2002). What does this price or value relation mean? If ecological resources are not produced in a factory and are external contributions to the economic system, the price corresponds to a rent or surplus payable to the owner of the ecological resource (O'Connor 1993a).

This system of regulation is an expression of the functioning of a subset of human societies and also reflects the fundamentally asymmetrical relations between the 
biosphere and the economy maintained by the capitalism system (O'Connor 1994). We need to distinguish between the two forms of appropriation. The first is the way in which production processes such as labor, forestry and agriculture are used and maintained. The second corresponds to the geological extraction of minerals and energy (Smith, McDonald, and Patterson 2014).

The model used in this paper is built by the author based on O'Connor's model (O’Connor 1993b). In it, the processes of production and physical consumption are linked, including the transformation of different inputs and material and energy resources, as well as exchanges or transfers between the processes. The technical coefficient matrices $(A)$ and $(B)$ are subdivided into $3 \times 3$ array submatrices.

In table 1, the donor subgroup provides resources to the internal production process and to the sinks. This is denoted by the subscript $D$. In the subgroup of internal processes, the subscript $M$ designates the inputs from donor processes and some outputs used in the sink process. The row with subscript $W$ designates the downstream processes dealing with the reception, stockage and valorization of waste from internal processes.

This model is then adapted into a detailed structure with two internal processes, two donor processes and one sink or valorization process. 
Table 1. Donor, internal and sinks processes

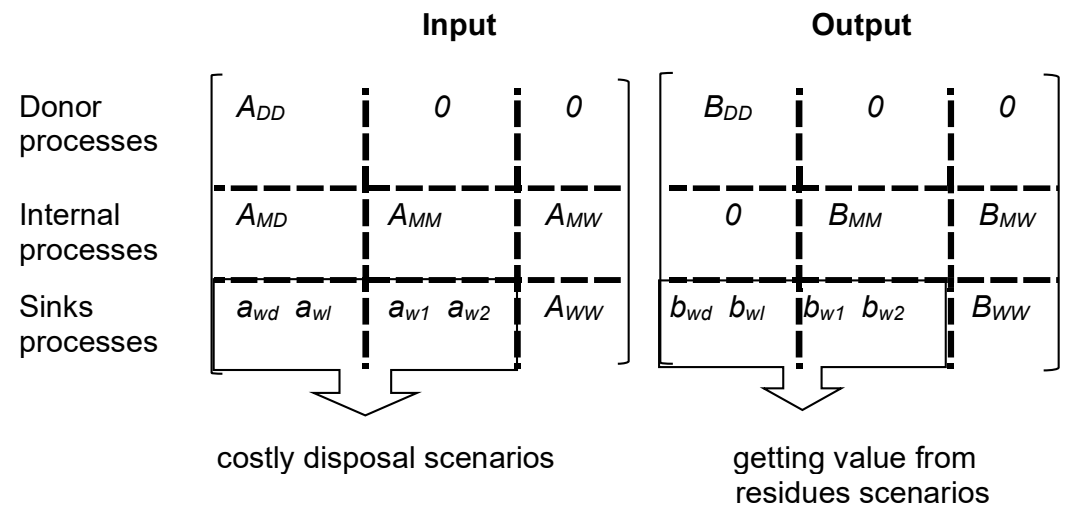

The matrices present four costly disposal scenarios with three intermediate cost variations:

- Scenario 1 needs economic good $a_{w 1}$

- Scenario 2 needs economic good $a_{w 2}$

- Scenario 3 needs to pay labor $a_{w l}$

- Scenario 4 needs an input from "outside" as an ecosystem service $a_{w d}$

The circular economy could, in principle, re-generate any of the three categories of valuable inputs, represented by the four scenarios:

- Scenario 5 produces a nature output $b_{w d}$

- Scenario 6 produces a laboroutput $b_{w l}$

- Scenario 7 produces an economic output $b_{w 1}$

- Scenario 8 produces an economic output $b_{w 2}$

We consider four input options ( 3 costly and 1 free disposal) and four output options (3 levels of recuperation and none) resulting in 16 fundamentally different combinations.

It is interesting to consider each of these 16 combinations, and to identify their distinguishing features in a dialectic way. In this paper, however, we will limit ourselves to a subset of cases, those associated with the recuperation of the economic good 
represented by $b_{w 2}>0$.

\subsection{Moore's dialectical method}

The natural capital appropriation process uses four basic inputs or "Four Cheaps" in Moore's language: these are cheap labor, food, energy and raw materials (Moore 2015). The combination of these four components generates and maintains a virtuous productive dynamic which generates rising profits.

This type of expansion process and biosphere appropriation has been expressed most dramatically in the conquest of the Americas by European powers through the instrumentalization of nature (Moore 2010a, 2010b). This mechanism has already been described and is considered in two stages: the integration of nature into the value system with waste outsourcing and the expansion of the exploitation boundaries (Murphy 2002).

In this sense, the problem with capitalism today is that the opportunities to appropriate the productive assets close to the borders of the exploitation zone are drastically reduced (Igoe, Neves, and Brockington 2010). As a result, the regulatory system is not able to control investment boundaries and the appropriation of ecological capital.

\section{Discussions}

This section outlines a set of processes involving material resources through the exploration of three case studies:

1- The case of "free gifts" and "free disposal" (FGFD).

2- The case of landfill waste without mechanisms to close the loop.

3- The case of surplus distribution 


\subsection{Free disposal}

The free disposal case considers the generic $4 \times 4$ matrix system. This case assumes labor costs to be equal to zero. We are interested in the algebraic solution of the $2 \times 2$ square internal-matrices $A$ and $B$. These are expressed as follows:

$$
\left[\begin{array}{ll}
4 & 2 \\
4 & 2
\end{array}\right]\left[\begin{array}{cc}
2 / 1 & 0 \\
0 & 2 / 1
\end{array}\right]\left[\begin{array}{l}
p_{1} \\
p_{2}
\end{array}\right]=\left[\begin{array}{cc}
24 & 16 \\
0 & 16
\end{array}\right]\left[\begin{array}{l}
p_{1} \\
p_{2}
\end{array}\right]
$$

The matrices can be expressed in linear equation format as follows:

Process $1 \quad 8 p_{1}+24 p_{2}=24 p_{1} \quad 24 p_{2}=16 p_{1} \quad 24 / 16=p_{1} / p_{2}$

Process $2 \quad 8 p_{1}+4 p_{2}=16 p_{2} \quad 8 p_{1}=12 p_{2} \quad p_{1} / p_{2}=12 / 8$

Please note that there is absolutely no difference between process 1 and process 2 : both give exactly the same result for $p_{1} / p_{2}$.

\subsection{Industrial recovery}

Saving raw material resources through industrial recuperation systems is a central issue for the green economy. In this case, waste is treated as an input for the production of the primary economic good in the first internal process assuming bw $2>0$ and aw $1>0$ as shown in Table 1 . The system can be displayed in $5 \times 5$ square matrices as follows:

Table 2. Industrial recuperation value system.

\begin{tabular}{|c|c|c|c|c|c|c|c|c|}
\hline \multirow[b]{2}{*}{$\begin{array}{l}\text { Donnor } \\
\text { processes }\end{array}$} & \multicolumn{4}{|c|}{ Input } & \multicolumn{4}{|c|}{ Output } \\
\hline & $\begin{array}{ll}a_{11} & 0 \\
0 & a_{22}\end{array}$ & $\begin{array}{ll}0 & 0 \\
0 & 0\end{array}$ & $\begin{array}{l}0 \\
0\end{array}$ & $\begin{array}{l}b_{11} \\
0\end{array}$ & $\begin{array}{l}0 \\
b_{22}\end{array}$ & $\begin{array}{l}0 \\
0\end{array}$ & $\begin{array}{l}0 \\
0\end{array}$ & $\begin{array}{l}0 \\
0\end{array}$ \\
\hline $\begin{array}{l}\text { Internal } \\
\text { processes }\end{array}$ & $\begin{array}{l}0 \\
0\end{array}$ & $\begin{array}{cc}4 & 12 \\
4 & 2\end{array}$ & $\begin{array}{l}0 \\
0\end{array}$ & $\begin{array}{l}0 \\
0\end{array}$ & $\begin{array}{l}0 \\
0\end{array}$ & $\begin{array}{l}24 \\
0\end{array}$ & $\begin{array}{c}0 \\
16\end{array}$ & $\begin{array}{l}0 \\
12\end{array}$ \\
\hline $\begin{array}{l}\text { Industrial recovery } \\
\text { process }\end{array}$ & 0 & 8 & 8 & 0 & 0 & 0 & 5 & 0 \\
\hline Let us write $\Sigma$ row & $=0$ & 1614 & 8 & 0 & 0 & 24 & 21 & 12 \\
\hline
\end{tabular}


Table 2 features $16+14=30$ input resource units and $24+21=45$ output resource units. This highlights the high cost of disposal with a 50\% annual growth rate for waste in capitalist economies.

In this study, we ignored the donor processes in our system in order to explore further the relationship betweenthe internalprocesses and the industrial recovery process.

$$
\left[\begin{array}{ccc}
4 & 12 & 0 \\
4 & 12 & 0 \\
8 & 0 & 8
\end{array}\right]\left[\begin{array}{ccc}
3 / 2 & 0 & 0 \\
0 & 3 / 2 & 0 \\
0 & 0 & 3 / 2
\end{array}\right]\left[\begin{array}{l}
p_{1} \\
p_{2} \\
p_{3}
\end{array}\right]=\left[\begin{array}{ccc}
24 & 0 & 0 \\
0 & 16 & 12 \\
0 & 5 & 0
\end{array}\right]\left[\begin{array}{l}
p_{1} \\
p_{2} \\
p_{3}
\end{array}\right]
$$

Each of the three equations gives us an expression for the relative price $p_{1} / p_{w}$ (price resource 1/waste price). For the top equation:

Process $1 \quad 6 p_{1}+18 p_{2}=24 p_{1} \rightarrow p_{1}=p_{2}$

Similarly:

Process $2 \quad 6 p_{1}+3 p_{2}=16 p_{2}+12 p_{3}$

This leads to an equivalent equation of $p_{1}=p_{2} \rightarrow 9 p_{1}-16 p_{1}=12 p_{3}$

$\rightarrow p_{3}=[(9-16) / 12] p_{1}$

Process $3 \quad 12 p_{1}+12 p_{w}=5 p_{2} \rightarrow$ with the relevant assumptions that $p_{1}=p_{2}$

$\rightarrow 7 p_{1}=-12 p_{w} \rightarrow p_{w}=-7 / 12 p_{1}$

\subsection{Surplus distribution between workers, owner and nature}

Analysis was done to examine how to distribute the profit generated between the workers and the owner of the means of production. This problemcan be analysed using the $2 \times 2$ square matrices, as follows: 


$$
\left[\begin{array}{cc}
4 & 12 \\
4 & 2
\end{array}\right]\left[\begin{array}{cc}
2 / 1 & 0 \\
0 & 2 / 1
\end{array}\right]\left[\begin{array}{l}
p_{1} \\
p_{2}
\end{array}\right]=\left[\begin{array}{cc}
24 & 0 \\
0 & 16
\end{array}\right]\left[\begin{array}{l}
p_{1} \\
p_{2}
\end{array}\right]
$$

Each of the equations gives us an expression for the relative price $p_{1} / p_{2}$. For the top equation:

Process $1 \quad 8 p_{1}+24 p_{2}=24 p_{1} 24 p_{2}=16 p_{1} \quad 24 / 16=p_{1} / p_{2}$

The following equation is derived from the second row of the matrix.

Process $2 \quad 8 p_{1}+4 p_{2}=16 p_{2} \rightarrow 8 p_{1}=12 p_{2} \rightarrow p_{1} / p_{2}=12 / 8$

In this case, the surplus is attributed to labor. This gives prices relative to the embodied (direct and indirect) labor requirements. It is convenient to express the pair of $2 \times 2$ square matrices, as follows:

$$
\left[\begin{array}{cc}
a_{1 z} & 0 \\
0 & a_{2 w}
\end{array}\right]\left[\begin{array}{c}
p_{z} \\
p_{w}
\end{array}\right]+\left[\begin{array}{cc}
4 & 12 \\
4 & 2
\end{array}\right]\left[\begin{array}{l}
p_{1} \\
p_{2}
\end{array}\right]=\left[\begin{array}{cc}
24 & 0 \\
0 & 16
\end{array}\right]\left[\begin{array}{l}
p_{1} \\
p_{2}
\end{array}\right]
$$

Process 1 uses a natural resource $(z)$ to generate an economic good. Process 2 uses labor $(w)$ in the manufacture of an economic good.

In order to solve the system equations, we solve for $a_{1 z} p_{z}$ using the terms of $p_{1}$ and $p_{2}$, as follows:

Process $14 p_{1}+12 p_{2}=24 p_{1} \rightarrow 12 p_{2}=20 p_{1} \rightarrow p_{2}=(5 / 3) p_{1} \quad$ The second row of the matrix can be written as:

Process $2 \quad a_{2 w} p_{w}+4 p_{1}+2 p_{2}=16 p_{2}$. We use the expression $p_{2}=(5 / 3) p_{1}$ to obtain $a_{2 w}$ $p_{w}+4 p_{1}=14(5 / 3) p_{1} \rightarrow a_{2 w} p_{w}=\left[(70-12) p_{1}\right] / 3=(58 / 3) p_{1}$. We choose $a_{2 w}=29$ to prove that $p_{w}=(2 / 3) p_{1}$.

In this case, all surplus generated is attributed to nature with $p_{w}=0$. We know that this gives prices relative to the embodied requirements from nature, as follows: 


$$
\left[\begin{array}{cc}
a_{1 z} & 0 \\
0 & a_{2 w}
\end{array}\right]\left[\begin{array}{c}
p_{Z} \\
0
\end{array}\right]+\left[\begin{array}{cc}
4 & 12 \\
4 & 2
\end{array}\right]\left[\begin{array}{l}
p_{1} \\
p_{2}
\end{array}\right]=\left[\begin{array}{cc}
24 & 0 \\
0 & 16
\end{array}\right]\left[\begin{array}{l}
p_{1} \\
p_{2}
\end{array}\right]
$$

Process 2 can be expressed as follows:

Process $24 p_{1}+2 p_{2}=16 p_{2} \rightarrow 4 p_{1}=14 p_{2} \rightarrow p_{2} / p_{1}=2 / 7$. Compare: $p_{2} / p_{1}=2 / 3$ with $\pi=$ 100\%. Table 3 summarizes surplus distribution results as follows:

Table 3. Profit and relative prices.

\begin{tabular}{cccc}
$\boldsymbol{\pi}$ & $\boldsymbol{z}$ & $\boldsymbol{w}$ & $\boldsymbol{p}_{2} / \boldsymbol{p}_{1}$ \\
\hline $\mathbf{1 0 0 \%}$ & 0 & 0 & $2 / 3$ \\
$\mathbf{0}$ & $100 \%$ & 0 & $2 / 7$ \\
$\mathbf{0}$ & 0 & $100 \%$ & $5 / 3$
\end{tabular}

Figure 1 presents the analysis of how these didactic examples might be reinterpreted using the notion of surplus distribution.

Fig 1. The notion of surplus repartition.

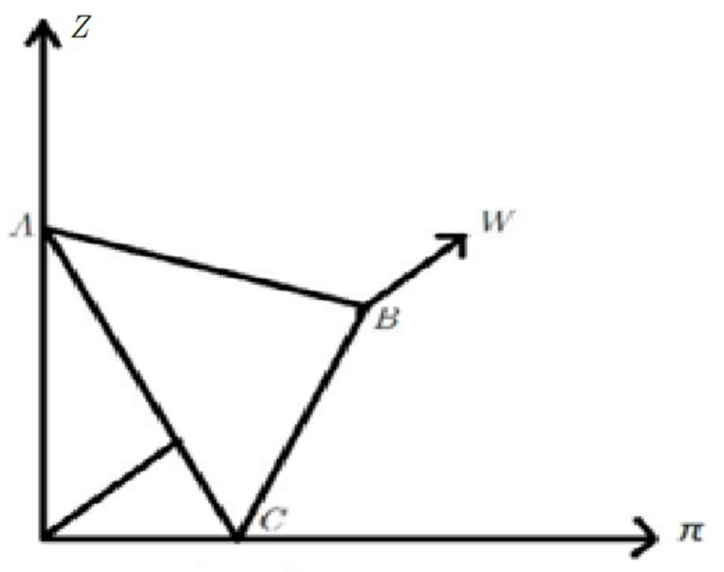

As shown in figure 1 , when $\pi=100 \%, \mathrm{z}=0$ and $w=0$, then all profits produced by the system areapportioned to the business owner. Alternatively, if $\pi=0, \mathrm{z}=0$ and $w=100 \%$, then all profits are given to the workforce thus obtaining a value system similar to Marx's labor theory of value (Marx 1867, 1969). It is also possible to return the value to the earth as a natural resource, thus obtaining a system of relative prices represented by the point 
where $\pi=0$ and $w=0$, which corresponds to a sustainable future (Ayres 2008; Costanza et al. 2014).

\subsection{Smalls wins and policy implications}

The concept of the circular economy is currently a popular notion with both policymakers and scientists. However, assumptions around the value theory, society structures, biosphere and the potential implementation of the circular economy remain largely unexplored. Korhonen, Nuur, et al. (2018) analyse how social and environmental problems are formulated on a global scale.

A policy solution to the problem of waste management was proposed by the European commission in 2015 with a policy entitled "Closing the Loop". The goal of this policy was to limit waste disposal through the development of new business models that would increase the research activities and create new green jobs (de Man and Friege 2016).

A progressive waste management system was designed, in which waste was minimized, reused or recycled. The aim was to ensure that nothing that could be reused or treated was incinerated (Bonciu 2014).

We argue that the European waste management policy was successful in reducing waste on a per capita basisand we compare the amount of waste reduced by different waste reduction modalities. Consequently, disposal through landfill and incineration has been decreasing. And the corollary is that energy recovery and recycling and composting activities have increased (see graphs 1 and 2 below). 
Graph 1. European union waste management in thousands of tonnes -28 countries

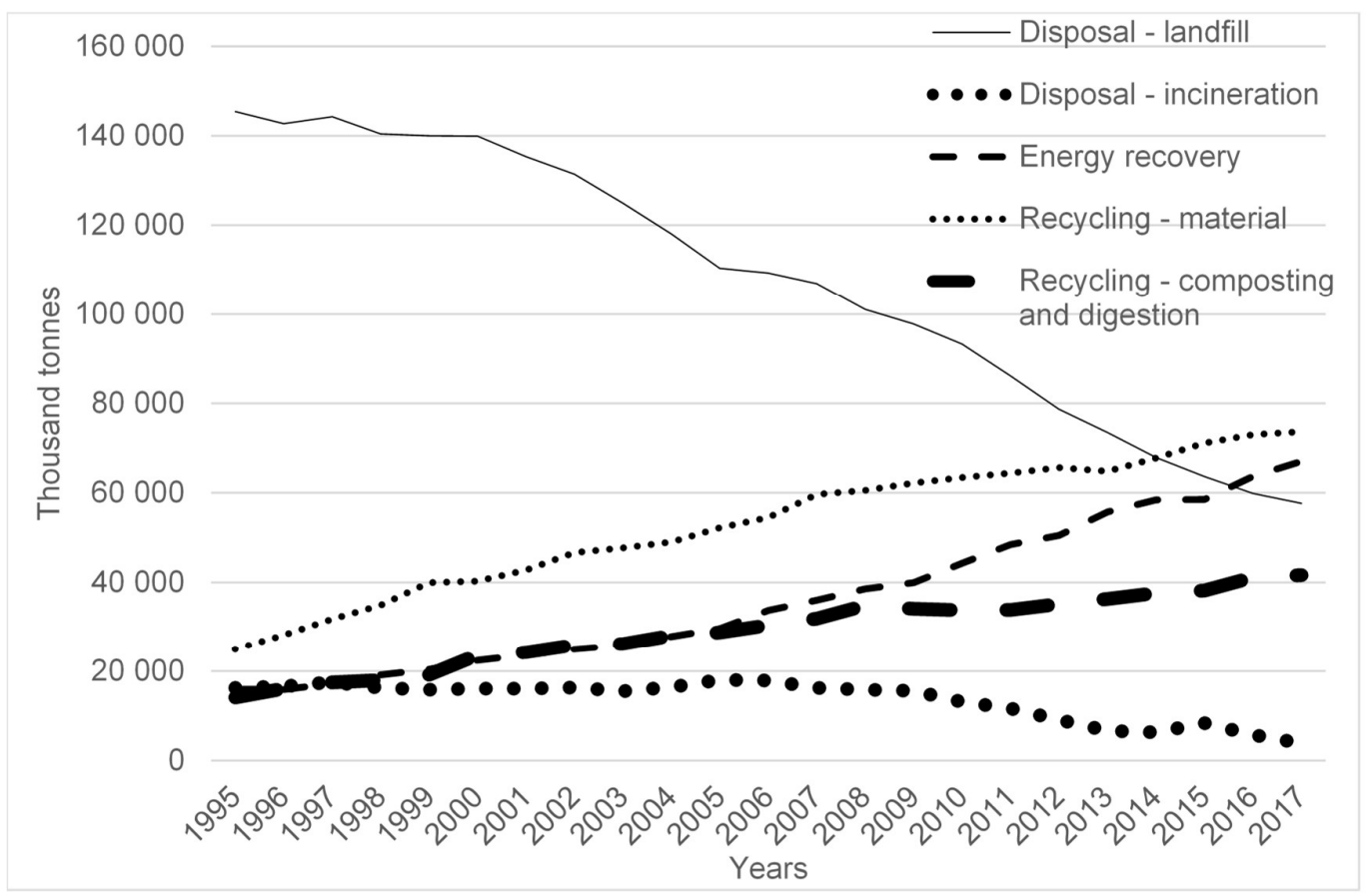

Eurostat (2019). Municipal waste by waste management operations [Data file].

Retrieved from http://appsso.eurostat.ec.europa.eu/nui/submitViewTableAction.do

Graph 2. European union waste management per capita - 28 countries

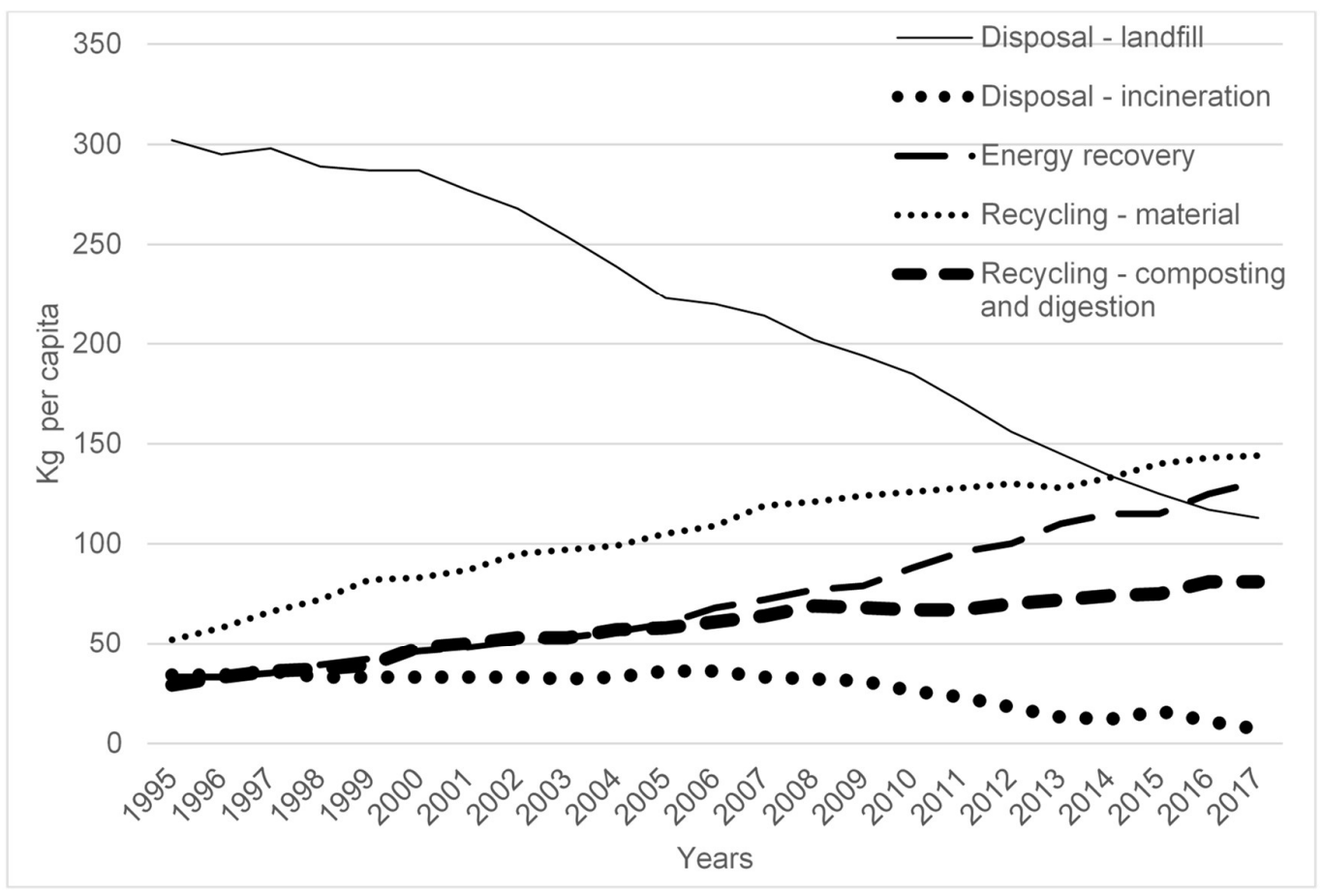

Eurostat (2019). Municipal waste by waste management operations [Data file]. Retrieved from http://appsso.eurostat.ec.europa.eu/nui/submitViewTableAction.do 
Waste can also be burned to produce heat or power, a procedure known as "waste to energy" (WtE). The organic portion of waste is viewed as an inexhaustible asset and qualifies for state appropriation under the EU's current plan for the development of sustainable power sources. Member nations are trying to benefit as much as possible from the subsidies available.

A tentative solution can be analysed using the "small wins theory". Big social problems become more approachable if they are divided into smaller challenges, with defined and accepted objectives (Weick 1984).

CatrienTermeer claims that targeting several smaller objectives allows great changes or goals of the circular economy to be achieved (Termeer and Dewulf 2019). Following this hypothesis, by applying small reforms through policies for the circular economy, the government could produce a larger cumulative impact on the environment.

Some policy examples are presented in the following table under the heading "small wins policies".

Table 4. Small wins examples.

\begin{tabular}{|c|c|}
\hline City and Country & Activity \\
\hline Austin, USA & Online marketplace for re-using materials \\
\hline Eskilstuna, Sweden & The world's first circular shopping centre \\
\hline Kristiansand, Norway & Citizen and business collaboration centre \\
\hline Kristiansand, Norway & Second hand store led by the municipal waste company \\
\hline New York, USA & Donation online market place and supporting initiatives \\
\hline Paris, France & Local production, repair and re-use initiatives \\
\hline Quezon, Philippines & $\begin{array}{l}\text { Regulations on the use of plastic bags to help curb ocean } \\
\text { plastics }\end{array}$ \\
\hline Stockholm, Sweden & The world's first large-scale 'biochar' urban carbon sink \\
\hline Vienna, Austria & $\begin{array}{l}\text { Initial government support helped to create Austria's largest } \\
\text { independent repair and service centre for electrical goods }\end{array}$ \\
\hline Santiago, Chile & New solutions in the treatment of waste and recycling \\
\hline
\end{tabular}

These are just some of the many examples of small wins policies and how people shape and are shaped by public policy. Let me raise an exemple of waste reduction and recycling in Chile where the creation and implementation of a waste transfer chain limits the effect of organisational waste on nature. TriCiclos started in Chile in 2009 with the expressed 
aim of moving to a "world without waste". Over this period, it has developed and operated the largest chain of recycling stations in South America, diverting 33,000 metric tonnes of recyclable material from landfill and reducing carbon emissions by more than 140,000 metric tonnes.

\section{Conclusions}

Sraffa's method assumes that the surplus is divided among the investors, the workers and the owners. So how do we distribute the surplus production of the atmosphere and of the lithosphere? How can the decision of how to allocate the surplus help to measure the biochemical cycles?

Sraffa's theory makes it possible to calculate the price and the profitability of the square matrices with a relative price or an exchange relationship between the goods. Thus, the answers lead to the conclusion that it is difficult to use a value system to measure the different numeraires taking into account their thermodynamic and entropic characteristics.

The biophysical dimension studied in our paper analyzes the circularity of the biochemical cycles. From this perspective, the circular economy is based on biophysical dimensions which are indispensable to any evaluation process of circularity.

Biophysical processes are not independent of each other, but rather are marked by strong interconnections which are the main problem when it comes to closing the loop. We try to reconcile interdependent and diverse objectives in order to analyze the pressure exerted by the drive to reduce waste and the ecological footprint on socio-economic activities.

Passet's notion is applied to biosphere exploitation systems to denote the productive 
capacity of their main components (the economic, social and technical elements of the exploited resources and the natural environment that accommodates them) and the functionalities that structure them. Consequently, any strategy to select the relevant indicators to close the loops for material and energy flows should reflect the current state, changes and structural characteristics of the economic system.

Using Sraffa's theory, we can observe that any arbitration between the "Four Cheap" resources is fundamentally political as political will dictates the target point between the point advocated by Marxist theory where all of the profits go to the workers $(w=100 \%)$ and the point defended by neoclassical theory $(\pi=100 \%)$ where all forms of capital economic, human and natural - are exploited by the capitalist system.

This appropriation mechanism of the economy considers the incorporation of nature resources and labor power into the value system, the outsourcing of final waste and the extension of the exploitation limits of the economy. This mechanism, inspired by Marx's concept of value integrates nature into the capitalist system to reflect the need to integrate processes that have, until now, been considered to be autonomous, for example, uncontrolled activities that occur in the wild. These activities are not included in the economic system, just as reproduction of the labor force is considered to be an external resource fund of the system. In this way, the paradigm of the circular economy operates both as part of the system of co-option of the environment and as part of the system for the protection of nature.

Finally, the nature protection goals of the circular economy are attainableif they are subdivided into smaller challenges. These policies may allow the government to implement small reforms that cumulatively produce a significant impact on the environment. 


\section{Acknowledgements}

The author would like to acknowledge and extend their gratitude to the University of

Paris-Est Marne-la-Vallée and the Research Group on the Use of Panel Data in

Economics (Erudite) for providing the means and facilities for research. The author also gratefully acknowledges the helpful comments provided on an earlier draft of this article

by Martin O'Connor, Professor of Economics at the University of Paris-Saclay.

\section{References}

Allenby, B. R. 1992. "Achieving Sustainable Development through Industrial Ecology." International Environmental Affairs 4(1):56-68.

Ayres, R. U. 1997. "Integrated Assessment of the Grand Nutrient Cycles." Environmental Modeling and Assessment 2(3):107-28.

Ayres, R. U. 1998. “The Price-Value Paradox.” Ecological Economics 25(1):17-19.

Ayres, R. U. 2008. “Sustainability Economics: Where Do We Stand?” Ecological Economics 67(2):281-310.

Billen, G., L. Lassaletta, and J. Garnier. 2014. "A Biogeochemical View of the Global Agro-Food System: Nitrogen Flows Associated with Protein Production, Consumption and Trade." Global Food Security 3(3-4):209-19.

Bonciu, Florin. 2014. "The European Economy: From a Linear to a Circular Economy." Romanian Journal of European Affairs 14(4):78-91.

Burmeister, E. 1984. "Sraffa, Labor Theories of Value, and the Economics of Real Wage Rate Determination.” Journal of Political Economy 92(3):508-26.

Carpenter, S. R. and E. M. Bennett. 2011. "Reconsideration of the Planetary Boundary for Phosphorus." Environmental Research Letters 6(1).

Chen, Y. T. 2016. "A Cost Analysis of Food Waste Composting in Taiwan." Sustainability (Switzerland) 8(11).

Costanza, R., G. Alperovitz, H. E. Daly, J. Farley, C. Franco, T. Jackson, I. Kubiszewski, J. Schor, and P. Victor. 2014. "What Would a Sustainable and Desirable Economy-in-Society-in-Nature Look Like?" Pp. 33-50 in Creating a Sustainable and Desirable Future: Insights from 45 Global Thought Leaders. World Scientific Publishing Co.

Crutzen, Paul J. 2006. “The 'Anthropocene.”' Pp. 13-18 in Earth system science in the anthropocene. Springer. 
Crutzen, Paul J. and Will Steffen. 2003. "How Long Have We Been in the Anthropocene Era?" Climatic Change 61(3):251-57.

Daly, H. E. 1985. "The Circular Flow of Exchange Value and the Linear Throughput of Matter-Energy: A Case of Misplaced Concreteness." Review of Social Economy 43(3):279-97.

Daly, H. E. 1992. "Is the Entropy Law Relevant to the Economics of Natural Resource Scarcity?- Yes, of Course It Is!" Journal of Environmental Economics and Management 23(1):91-95.

Daly, H. E. 2011. "Moving from a Failed Growth Economy to a Steady-State Economy." Pp. 176-89 in Towards an Integr. Paradigm in Heterodox Economics: Alternative Approaches to the Current Eco-Social Crises. Palgrave Macmillan.

Deléage, J. P. 1989. "Eco-Marxist Critique of Political Economy." Capitalism Nature Socialism 1(3):15-31.

Domene, L. A. F. and R. U. Ayres. 2001. "Nitrogen's Role in Industrial Systems." Journal of Industrial Ecology 5(1):77-103.

Duchin, Faye. 2009. "Input-Output Economics and Material Flows.” Pp. 23-41 in Handbook of input-output economics in industrial ecology. Springer.

EIT Climate-KIC (2018) Municipality-led circular economy case studies. Retrieved from https://circulareconomy.europa.eu/plat form/en/knowledge/municipalityled-circular-economy-casestudies

Foster, J. B. and P. Burkett. 2004. "Ecological Economics and Classical Marxism: The 'Podolinsky Business' Reconsidered.” Organization and Environment 17(1):3260.

Geissdoerfer, Martin, Paulo Savaget, Nancy MP Bocken, and Erik Jan Hultink. 2017. "The Circular Economy-A New Sustainability Paradigm?" Journal of Cleaner Production 143:757-68.

Giampietro, M. 2019. "On the Circular Bioeconomy and Decoupling: Implications for Sustainable Growth.” Ecological Economics 162:143-56.

Grizzetti, B., U. Pretato, L. Lassaletta, G. Billen, and J. Garnier. 2013. “The Contribution of Food Waste to Global and European Nitrogen Pollution." Environmental Science and Policy 33:186-95.

Haas, Willi, Fridolin Krausmann, Dominik Wiedenhofer, and Markus Heinz. 2015. "How Circular Is the Global Economy?: An Assessment of Material Flows, Waste Production, and Recycling in the European Union and the World in 2005." Journal of Industrial Ecology 19(5):765-77.

Hutchinson, G. Evelyn. 1948. "Circular Causal Systems in Ecology." Annals of the New York Academy of Sciences 50(4):221-246. 
Igoe, Jim, Katja Neves, and Dan Brockington. 2010. "A Spectacular Eco-tour around the Historic Bloc: Theorising the Convergence of Biodiversity Conservation and Capitalist Expansion.” Antipode 42(3):486-512.

Korhonen, Jouni, Antero Honkasalo, and Jyri Seppälä. 2018. "Circular Economy: The Concept and Its Limitations.” Ecological Economics 143:37-46.

Korhonen, Jouni, Cali Nuur, Andreas Feldmann, and Seyoum Eshetu Birkie. 2018. "Circular Economy as an Essentially Contested Concept." Journal of Cleaner Production 175:544-552.

Le Noë, J., G. Billen, and J. Garnier. 2017. "How the Structure of Agro-Food Systems Shapes Nitrogen, Phosphorus, and Carbon Fluxes: The Generalized Representation of Agro-Food System Applied at the Regional Scale in France." Science of the Total Environment 586:42-55.

Levin, Simon A. 1992. "The Problem of Pattern and Scale in Ecology: The Robert H. MacArthur Award Lecture." Ecology 73(6):1943-67.

Levin, Simon A. and Simon Lelvin. 1999. Fragile Dominion: Complexity and the Commons. Perseus Books Reading, MA.

Loiret, Richard. 2016. “Le Bilan Écologique. Mesurer La Perturbation Anthropogénique de l'Ecosphère et de La Biosphère (Un Bilan de l'Anthropocène). Caractériser Les Voies Du Développement Écologique Des Territoires.” Paris Saclay.

Lotka, Alfred J. 1922. "Natural Selection as a Physical Principle." Proceedings of the National Academy of Sciences of the United States of America 8(6):151.

Lotka, Alfred J. 1926. "Elements of Physical Biology." Science Progress in the Twentieth Century (1919-1933) 21(82):341-43.

de Man, Reinier and Henning Friege. 2016. Circular Economy: European Policy on Shaky Ground. SAGE Publications Sage UK: London, England.

Marx, K. 1867. “Capital.” 1.

Marx, K. 1969. “Theories of Surplus Value.” 1.

McDonough, William and Michael Braungart. 2010. Cradle to Cradle: Remaking the Way We Make Things. North point press.

Moore, Jason. 2015. Capitalism in the Web of Life : Ecology and the Accumulation of Capital. New York London: Verso.

Moore, Jason W. 2010a. “'Amsterdam Is Standing on Norway' Part I: The Alchemy of Capital, Empire and Nature in the Diaspora of Silver, 1545-1648." Journal of Agrarian Change 10(1):33-68.

Moore, Jason W. 2010b. ““Amsterdam Is Standing on Norway’ Part II: The Global North Atlantic in the Ecological Revolution of the Long Seventeenth Century." Journal of Agrarian Change 10(2):188-227. 
Murphy, Raymond. 2002. "The Internalization of Autonomous Nature into Society." The Sociological Review 50(3):313-33.

O'Connor, Martin. 1993a. "On the Misadventures of Capitalist Nature." Capitalism Nature Socialism 4(3):7-40.

O'Connor, Martin. 1993b. "Value System Contests and the Appropriation of Ecological Capital.” The Manchester School of Economic \& Social Studies 61(4):398-424.

O’Connor, Martin. 1994. Is Capitalism Sustainable? : Political Economy and the Politics of Ecology. New York: Guilford Press.

Odum, Eugène. 1971. Fundamentals of Ecology. 3ème éd.. Philadelphia London Toronto: Saunders.

Patterson, M. G. 2002. "Ecological Production Based Pricing of Biosphere Processes." Ecological Economics 41(3):457-78.

Podolinsky, Sergei. 1880. "Le Socialisme et l'unité Des Forces Physiques." La Revue Socialiste (8):353-65.

Smith, N. J., G. W. McDonald, and M. G. Patterson. 2014. "Is There Overshoot of Planetary Limits? New Indicators of Human Appropriation of the Global Biogeochemical Cycles Relative to Their Regenerative Capacity Based on 'ecotime' Analysis.” Ecological Economics 104:80-92.

Sraffa, P. 1960. "Production of Commodities by Means of Commodities." Production of Commodities by Means of Commodities.

Steffen, Will, Paul J. Crutzen, and John R. McNeill. 2007. "The Anthropocene: Are Humans Now Overwhelming the Great Forces of Nature." AMBIO: A Journal of the Human Environment 36(8):614-22.

Taylor, Peter J. 2010. Unruly Complexity: Ecology, Interpretation, Engagement. University of Chicago Press.

Termeer, Catrien JAM and Art Dewulf. 2019. "A Small Wins Framework to Overcome the Evaluation Paradox of Governing Wicked Problems." Policy and Society 38(2):298-314.

Vernadsky, V. I. 1926. The Biosphere. Leningrad, Nauchtekhizdat (in Russian).

Weick, K. E. 1984. "Small Wins: Redefining the Scale of Social Problems." American Psychologist 39(1):40-49.

World Economic Forum (2019) These 11 companies are leading the way to a circular economy. Retrieved fromhttps://www. weforum.org/agenda/2019/02/companiesleading-way-to-circu lar-economy/

Zink, Trevor and Roland Geyer. 2017. "Circular Economy Rebound." Journal of Industrial Ecology 21(3):593-602. 
